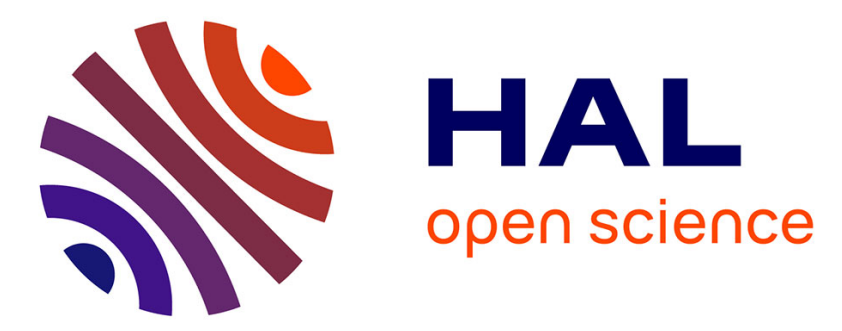

\title{
Probabilistic hazard analysis for tsunamis generated by subaqueous volcanic explosions in the Campi Flegrei caldera, Italy
}

Raphael Paris, M. Ulvrova, J. Selva, B. Brizuela, A. Costa, A. Grezio, S. Lorito, R. Tonini

\section{To cite this version:}

Raphael Paris, M. Ulvrova, J. Selva, B. Brizuela, A. Costa, et al.. Probabilistic hazard analysis for tsunamis generated by subaqueous volcanic explosions in the Campi Flegrei caldera, Italy. Journal of Volcanology and Geothermal Research, 2019, 379, pp.106-116. 10.1016/j.jvolgeores.2019.05.010 . hal-02531269

\section{HAL Id: hal-02531269 \\ https://hal.uca.fr/hal-02531269}

Submitted on 22 Oct 2021

HAL is a multi-disciplinary open access archive for the deposit and dissemination of scientific research documents, whether they are published or not. The documents may come from teaching and research institutions in France or abroad, or from public or private research centers.
L'archive ouverte pluridisciplinaire HAL, est destinée au dépôt et à la diffusion de documents scientifiques de niveau recherche, publiés ou non, émanant des établissements d'enseignement et de recherche français ou étrangers, des laboratoires publics ou privés.

\section{(c) (1) $\$$}

Distributed under a Creative Commons Attribution - NonCommercial| 4.0 International 


\section{Probabilistic hazard analysis for tsunamis generated by subaqueous 2 volcanic explosions in the Campi Flegrei caldera, Italy}

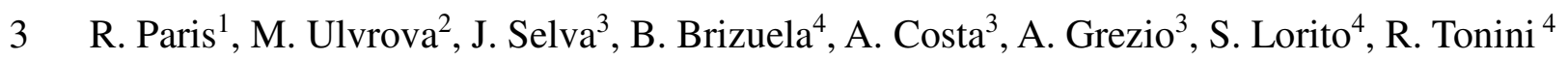

4

5

* Corresponding author at: Université Clermont Auvergne, CNRS, IRD, OPGC, Laboratoire Magmas et Volcans, F-63000 Clermont-Ferrand, France.Tel.+33 473346717. E-mail. Raphael.Paris@uca.fr

\section{Abstract}

A probabilistic hazard analysis of tsunami generated by subaqueous volcanic explosion is applied to the Campi Flegrei caldera (Campania, Italy). An event tree is developed to quantify the tsunami hazard due to the submarine explosions by: $i$ ) defining potential size classes of explosion magnitude on the basis of past volcanic activity in the Campi Flegrei caldera and sites in the underwater part of the caldera; $i$ ) simulating the generation and propagation of the consequent tsunami waves able to reach the coasts of the Campania region for all combinations of tsunami-generating vents and sizes; and iii) quantifying the tsunami probability and relative uncertainty, conditional upon the occurrence of an underwater eruption at Campi Flegrei. Tsunami hazard generated by subaqueous volcanic explosions is considered crucial because of its potential high impact on the densely populated coastal areas of the Pozzuoli Bay and Gulf of Naples even if the probability for eruptions in the submarine part of the caldera is certainly low. The tsunami hazard analysis is presented using conditional hazard curves and maps, that is calculating the probability (and relative uncertainties) of exceeding given tsunami intensity thresholds (wave amplitudes at the coast), given the occurrence of a subaqueous eruption. The results indicate that a significant tsunami hazard exists in many areas of the Bay of Naples. 


\section{Introduction}

Tsunamis generated by eruptive and gravitational processes on the flanks of volcanic edifices are quite infrequent (about 5\% of all recorded tsunamis: Latter, 1981), but they represent the third cause of fatalities due to volcanism, with four tsunamigenic eruptions being ranked in the twenty deadliest volcanic disasters (e.g. Auker et al., 2013). Tsunami hazards related to subaqueous eruptions are particularly challenging to evaluate and forecast, due to a lack of geological, observational and instrumental data, in particular in densely populated regions such as the Campi Flegrei caldera in Italy (Fig. 1).

Different tsunami source mechanisms can be involved during a subaqueous eruption: pyroclastic flows, debris flows, caldera collapses and explosions (Paris, 2015). Tsunami generation by subaqueous volcanic explosions is controlled by a range of physical parameters including water depth, size of eruptive vent, energy and depth of explosion, and complex magma-water interactions which determine the explosion itself (Le Méhauté, 1971; Kokelaar, 1986; Wohletz, 1986; Mirchina \& Pelinovsky, 1988; Duffy, 1992; Le Méhauté \& Wang, 1996; Kedrinskii, 2005; Egorov, 2007; Morrissey et al., 2010). The explosion forms an initial craterlike cavity at the water surface (Fig. 2a), with a cylindrical bore that expands radially to form the leading wave, followed by a wave trough. Initial surface displacement of the water surface (i.e. maximum height of the bore) can be empirically estimated directly as a function of explosion energy at a given water depth and size of the formed eruptive vent (Le Méhauté, 1971; Sato \& Taniguchi, 1997; Goto et al., 2001). The initial downward displacement of the water column (i.e. the cavity) is followed by an upward displacement, thus forming a steep cone of water in the centre. This cone then collapses and turns to a second cylindrical bore, as demonstrated by experimental explosions and numerical simulations (e.g. Le Méhauté \& Wang, 1996; Kedrinskii, 2005; Torsvik et al., 2010; Ulvrova et al., 2014 \& 2016; Paris \& Ulvrova, 2019). 
61 Different methods of Probabilistic Tsunami Hazard Analyses (PTHA) have been developed during the two last decades (Grezio et al., 2017). PTHA provides the likelihood of a given parameter of the tsunami (e.g. wave height at the coast, flow velocity, flow depth, runup height, or inundation distance) being exceeded at a particular location within a given period of time. PTHA can combine geological, historical and instrumental data both of tsunamis (e.g. sedimentary deposits, catalogues and historical accounts, tide-gauge records or pressure sensor time-series), and of tsunami sources (source parameters, such as fault and seismicity catalogue for earthquake sources), using statistical techniques and numerical simulations. Due to the low relative frequency of tsunamis, concurring with the lack of repeated tsunami run-up data spanning a long enough time period at a given location, the common practice is to propose numerous different tsunami source scenarios with their associated probability (Geist and Lynett, 2014). These scenarios are assumed to be a complete representation of the expected natural variability (Selva et al., 2016). However, PTHA methods for landslide and volcanic sources of tsunamis are far less established compared to the earthquake sources (Grezio et al., 2017). Here, we produce a first attempt of considering volcanic sources. We focus on conditional PTHA, that is, conditional upon the occurrence of a volcanic phenomenon potentially generating a tsunami (i.e. submarine eruptions). The quantification of long-term conditional hazard is common in volcanic hazard studies, since it allows for planning evacuation in case of eruption (e.g. update of the National Emergency Plan for Campi Flegrei, 2016: http://www.protezionecivile.gov.it/en/mediacommunication/dossier/detail/-/asset_publisher/default/content/aggiornamento-del-pianonazionale-di-emergenza-per-i-campi-flegrei), as well as it provides reference simulations for short-term hazard quantifications (e.g., Selva et al., 2014). Its extension to absolute PTHA may be obtained by multiplying conditional hazard by the probability of occurrence of volcanic eruption. With more than 20 eruptions in the last $5 \mathrm{ka}$ (e.g. 25 eruptions listed by Orsi et al., 2009), eruptions at Campi Flegrei have a mean annual rate on the order of $10^{-3}$ per year. However, we did not attempt here the estimation of any temporal component of the hazard, which is not trivial being volcanic eruptive sequences clearly not stationary in time (Bevilacqua et al., 2016).

In this study, we consider different scenarios of tsunamis generated by explosions in the offshore part of the Campi Flegrei caldera (Campania, Italy) and their effects on the coasts of the Pozzuoli Bay, the islands of Ischia and Capri, and the Gulf of Naples (Figs. 1 and 2a). These scenarios include different potential sizes and vent positions within the Campi Flegrei 
caldera. They are then combined according to their probability of occurrence, quantifying the consequent hazard in terms of conditional PTHA. The nested caldera of Campi Flegrei is a complex partly submerged volcanic structure created mainly by multiple caldera forming events: the 39 ka Campanian Ignimbrite, the 29 ka Masseria del Monte Tuff, and the $12 \mathrm{ka}$ Neapolitan Yellow Tuff (e.g. Deino et al., 2004; Marti et al., 2016; Albert et al., 2019). During the last $12 \mathrm{ka}$, periods of high-frequency volcanism (mean intervals of 50-70 years) were separated by periods of quiescence lasting from 1 to $3.5 \mathrm{ka}$ (Di Vito et al., 1999). While the onshore eruptive history of the caldera is well documented, past volcanic activity offshore and the probability for future eruptions in the submarine part of the caldera (Pozzuoli Bay) have been rarely discussed (Tonini et al., 2015; Selva et al. 2012a). Recent seismic and magnetic surveys allowed the structural and magmatic evolution of the submerged southern half of the caldera to be reconstructed (Aiello et al., 2012; Steinmann et al., 2018). The explosivity of coastal-to-submarine eruptions such as Nisida Bank ( 10 ka), Nisida Island ( 4 ka), and Capo Miseno ( 3.7 ka) was recently reassessed to at least VEI 3 (Steinmann et al., 2018). Highly permeable ring-faults along the southern rim of the caldera are prone to magma ascent (Steinmann et al., 2018) and represent potential sites for future eruptions (Selva et al., 2012a). Moreover, structural and geophysical data indicate the presence of several major faults in the submerged part of the caldera, representing potential weakness areas in which eruption may be favoured (Selva et al., 2012a). Along these structures, the last eruption of Campi Flegrei (Monte Nuovo, A.D. 1538) occurred starting at sea (Guidoboni and Ciuccarelli, 2011; Di Vito et al. 2016).

\section{Methods}

The methodology presented in this paper is based on the development of an event tree (Newhall and Hobblit, 2002) for quantifying the tsunami hazard due to submarine explosions. This method is based on 3 major steps: (1) the event tree was set by identifying 17 potential vent areas in the underwater part of the Campi Flegrei caldera and 4 size classes of eruptive events (three of which tsunami-generating explosive eruptions), allowing the definition of $17 \times 3$ representative tsunami-generating scenarios; (2) all the representative scenarios were simulated, generating and propagating the consequent tsunami waves able to reach the coasts of the Campania region; (3) the conditional probability of each representative scenario given the occurrence of one eruption at sea was estimated, and combined with the corresponding 
126 simulated tsunami scenarios, to produce the final conditional PTHA in the event-tree 127 framework.

\subsection{Setting the event tree to represent vent and size variability of eruptions}

130 We considered here only those explosions deemed capable to generate tsunamis, i.e. eruptions occurring at sea with depth greater than $10 \mathrm{~m}$. The adopted event tree for the Campi Flegrei caldera (Fig. 3) is the modified Bayesian Event Tree for Volcanic Hazard (BET_VH) by Selva et al. (2010). Nodes 1-2-3 can be neglected, since probabilities are conditioned upon the occurrence of an eruption. Then, the residual event tree is composed only by 4 levels, which are relative to vent position, eruption size, and tsunami generation and intensity (nodes 4, 5, and 6-7-8, following Marzocchi et al. 2010).

At node 4 (vent position on Fig. 3), we reduced the original discretization from Selva et al. (2012a) in order to decrease the computational cost of the subsequent tsunami simulations, adopting a regular grid with cell size of $1500 \times 1500 \mathrm{~m}$. Limiting only to the areas with not null conditional probability and water depth $\mathrm{D}>10 \mathrm{~m}$, we selected 17 equally spaced cells in the

141 Pozzuoli Bay (Fig. 2b) as potential eruptive sites. Note that the explosion depth $(d)$ used in the simulations is similar to water depth $(D)$ and ranges between 23 and $111 \mathrm{~m}$ (Table 1).

143 At node 5, we adopted the four size classes for eruptions proposed by Orsi et al. (2009), in

144 line also with most of subsequent probabilistic volcanic hazard quantifications at Campi 145 Flegrei (Costa et al., 2009; Selva et al. 2010, 2014, 2018; Tonini et al. 2015, Sandri et al., 146 2016). Only 3 out of the size classes are relative to explosive eruptions. To characterize these 147 explosive classes in terms of tsunami-generation potential, we estimated the corresponding 148 crater dimensions using an analysis of the past activity in the caldera in three different epochs 149 of volcanic activity (Orsi et al., 2009). In epoch 1 (15-9.5 ka Before Present) 34 explosive 150 eruptions occurred, in epoch 2 (8.6-8.2 ka BP) 6 explosive eruptions and in epoch 3 (4.8-3.8 151 ka BP) 22 explosive and 3 effusive eruptions (di Vito et al., 1999; Orsi et al., 2009) (Fig. 2c 152 and $2 \mathrm{~d}$ ). On the basis of the correspondent crater characteristics, the explosive eruptions are 153 grouped in three size classes in terms of vent radius, corresponding to different explosive 154 energies. Thus, we selected 3 radius values $(200,650$, and $900 \mathrm{~m})$ as representative of the 155 three eruption classes. We assume that both submerged and emerged areas of the Campi 156 Flegrei undergo to similar explosive processes in the caldera. 
157 At node 6, we considered only tsunamis generated by explosive eruptions. Of course, other 158 volcanic processes, such as flank collapses or pyroclastic density currents entering the sea, may generate tsunami waves

160 At node 7-8 (Fig. 3), we adopted a "representative scenario" approach (Selva et al. 2010). In 161 this approach, each of the combinations of the 17 cells and 3 size classes is represented by a 162 single scenario with representative parameters (cell centre and representative radius), instead 163 of modelling the variability of both vent positions in each cell and crater sizes in each size 164 class (Sandri et al. 2016). In this way, the latter variability (intra-class) is assumed negligible 165 with respect to the inter-class variability (the one between the different representative vent 166 and size classes). Sandri et al. (2016) demonstrated that this approach is reasonable as first 167 order approximation for tephra fallout in the Probabilistic Volcanic Hazard Analysis (PVHA) 168 at both Somma-Vesuvius and Campi Flegrei, by quantifying the bias induced by adopting one single representative scenario instead of sampling its natural variability. Given that we adopted the same discretization for size classes, we assume that this can be extended to the tsunami hazard. As a consequence, we defined $17 \times 3$ representative scenarios of explosions with vent positioned in the geometrical centre of each of the 17 cells, and representative radius of 200, 650, and $900 \mathrm{~m}$ for the three explosive classes.

\subsection{Numerical simulations of explosion and tsunami}

176 All the combinations of representative 17 vent locations and 3 vent sizes should be considered 177 as potential source for tsunamis. The energy of the explosion is estimated following the 178 empirical relationship given by Sato and Taniguchi (1997):

180 where $E$ is the explosion energy in Joules and $R$ the radius of the eruptive vent in meters. 181 Following the method proposed by Torsvik et al. (2010) and Ulvrova et al. (2014, 2016), and 182 using the empirical formula of Le Méhauté and Wang (1996), the initial surface displacement 183 generated by the explosion is a parabolic cavity with a vertical steep water rim. The size of 184 the water cavity ( $R_{c}$, in meters) is then estimated based on explosion energy using relationship 185 (Le Méhauté and Wang, 1996): 
187 The initial maximum vertical water surface displacement $\eta_{0}$ of the cavity rim is also a 188 function of explosion energy at a given depth following:

190 based on the empirical formula of Le Méhauté and Wang (1996, with $\eta_{0}$ is in meters, and $c$ is 191 an empirical dimensional constant. According to the explosion yield and water depth, two 192 cases are distinguished (Le Méhauté and Wang, 1996): (1) $c=0.0143$ if $6.15 \times 10^{-4}<d / E^{1 / 3}<$ $1931.85 \times 10^{-2}$ (where $d$ is the depth of explosion in metres); or (2) $c=0.0291$ if $d / E^{1 / 3}<6.15 \times 10^{-4}$.

194 Values of explosion energy $(E)$ and corresponding initial surface displacement $\left(\eta_{0}\right)$ of the 51 195 simulated scenarios are listed in Table 1.

196 All numerical simulations were performed using FUNWAVE-TVD code solving for the fully 197 non-linear Boussinesq-type wave equations in spherical coordinates (Kirby et al., 1998; Shi et 198 al., 2012; Tehranirad et al., 2013). Boussinesq model includes the effects of amplitude non199 linearity and frequency dispersion in the case of intermediate-to-deep water waves (up to 200 wavelengths equivalent to water depth) although we neglect the effect of bottom friction. The 201 third-order Runge-Kutta method is used to advance the model in time. An adaptive time step 202 is chosen following the Courant-Friedrichs-Lewy criterion. To ensure the stability of the 203 scheme, we set the Courant number to 0.5 and keep it constant for all simulations. Fourth204 order spatial discretization is employed. We exploit only the maximum amplitude of the 205 incoming waves at the shoreline and neglect the inundation phase. We run the simulations for 20625 minutes of the model time. In order to prevent reflections from the end-walls at the open 207 sea, we impose a $3 \mathrm{~km}$ wide sponge layer at the limit of the computational domain.

208 The spherical grid has a resolution of $39 \mathrm{~m} \times 50 \mathrm{~m}(893 \times 1595$ grid nodes $)$ in the longitudinal 209 and latitudinal directions, respectively, covering about an area of $3000 \mathrm{~km}^{2}$ between Ischia, 210 Capri and Naples (Fig. 1). The grid was built by integrating printed nautical charts to digital 211 elevation (Tarquini et al., 2007) and bathymetric models (D'Argenio et al., 2004) available for 212 the study area. Typical water depth in the Gulf of Naples and Pozzuoli Bay ranges between 50 213 and $200 \mathrm{~m}$. Wave heights at the coast were computed at >200 virtual tide gauge stations from 214 Pozzuoli to Amalfi, including Ischia and Capri Islands. 
217 The probability at nodes 4 and 5 of the Event Tree are retrieved from literature. In particular, 218 for node 4, we adopted the probability proposed by Selva et al. (2012a), cumulating the 219 distribution parameters of the undersea (depth $>10 \mathrm{~m}$ ) cells closer to our 17 selected vent positions. This probability distribution is not uniform, being eruptions in the centre of the gulf more probable due to the presence of main NE-SW trending fault system. At node 5, we adopted the distribution parameters of Orsi et al. (2009), as updated in Selva et al. (2018), with a decreasing probability for increasing explosion size.

At node 6, we assume that effusive eruptions certainly do not produce tsunamis (conditional probability equal to 0 and no epistemic uncertainty), while explosive eruptions certainly produce tsunamis (conditional probability equal to 1 ).

At nodes 7-8, as tsunami intensity measure we selected the maximum wave amplitude (Hmax) recorded at the coast (at a water depth of $1 \mathrm{~m}$ ). Hazard curves were built at 421 target points along the coast, from Cuma to Positano. To account for the rather rough discretization of the aleatory distribution on source space (based on a broad grid for the vents and only 3 potential sizes), as well as for the intrinsic uncertainty in the generation and propagation of the tsunami, we introduced some level of uncertainty to the simulation results (Glimsdal et al., 2019). We assumed that each scenario is associated to a conditional hazard curve (conditional upon a scenario in that vent area and that size class) described by a log-normal distribution (see Davies et al. 2017, and references therein). The parameters of the distribution ( $\mu$ and $\sigma$, mean and standard deviation of the logarithmic values, respectively) were set based on simulation results. Specifically, we set $\mu$ as the average value of the $\log ($ Hmax $)$, while a rather large variance is assumed by setting $\sigma=1$ (slightly larger than the one adopted for earthquake generated tsunamis in Davies et al. 2017). Given the first order approximation made by defining in this way the log-normal distribution, we set to the obtained conditional hazard curves the maximum allowed epistemic uncertainty (equivalent sample size equal to 1).

\section{Results}


The three scenarios of explosions with vent radius, $R$, of 200,650 , and $900 \mathrm{~m}$, correspond to explosion energies, $E$, of $2.9 \times 10^{14}, 9.8 \times 10^{15}$, and $2.6 \times 10^{16} \mathrm{~J}$ (Table 1). Following Eq. (3), these explosions create an initial surface displacement of the water surface, $\eta_{0}$, of 85, 200, and $250 \mathrm{~m}$, respectively (Table 1). Tsunami waves generated by the explosion propagate radially away from the explosion centre, all over the computational area, with a significant influence of the bathymetry (e.g. higher wave heights due to shallow banks around the Dohrn and Magnaghi canyons in Fig. 4) and coastal morphology (e.g. effects of wave refraction around the islands and capes in Fig. 4).

The highest tsunami impact is recorded on the coasts of the Pozzuoli Bay that are in the imminent vicinity of the explosion centres. Maximum wave heights at the coast exceed $3 \mathrm{~m}$ only in the Pozzuoli Bay and the eastern coast of Procida Island. Wave heights decrease by a factor of 10 from the explosion site to the Gulf of Naples (note logarithmic scale of wave heights on Fig. 4), where all sites record waves lower than $1.5 \mathrm{~m}$ for the scenarios with $R=$ $900 \mathrm{~m}$ and lower than $0.5 \mathrm{~m}$ for the scenarios with $R=650 \mathrm{~m}$. As a result of wave refraction, secondary peaks of wave heights are observed on the western coast of the Sorrento Peninsula and eastern coast of Capri Island (i.e. at distances between 80 and $110 \mathrm{~km}$ on Fig. 5).

For a vent radius of $900 \mathrm{~m}\left(\eta_{0}=250 \mathrm{~m}\right)$, wave heights higher than $10 \mathrm{~m}$ are restricted to the coasts of the Pozzuoli Bay (Figs. 4 and 5). Lowering vent radius to $650 \mathrm{~m}\left(\eta_{0}=200 \mathrm{~m}\right)$ reduces wave heights in the bay by a factor of 1.5 to 2 (Fig. 5). Wave height profiles recorded at different tide gauge stations show that the scenarios with vent radius of $900 \mathrm{~m}$ generate waves twice as high as the one with vent radius of $650 \mathrm{~m}$ (Fig. 6). Apart from this difference, the two cases display the same wave patterns. Explosions corresponding to a vent radius of $200 \mathrm{~m}\left(\eta_{0}=85 \mathrm{~m}\right)$ generate waves lower than $1 \mathrm{~m}$ high, even on the coasts of the Pozzuoli Bay (Figs. 5 and 6), except at vent sites \#16 and \#17 (Fig. 2b) which are located near the coast. In this case, waves locally reach amplitudes up to 2 meters (Fig. 5).

The propagation of the tsunami in the entire Gulf of Naples takes approximately 15 minutes. Waves reach Pozzuoli in 2 minutes, Procida in 4 minutes, Naples in 7 minutes, Capri in 9 minutes, and Castellamare di Stabia in 13 minutes (Fig. 6). The positive leading wave (peak)

274 is the highest one, except for the stations located on the opposite side of the Gulf of Naples 275 (e.g. Castellamare di Stabia, Capri). In the proximal field, the leading wave represents the 276 short-period component of the wave spectrum (e.g. Pozzuoli, Procida, and Naples). As the 277 distance from the explosion increases, the arrival of longer-period waves might predate the 
short-period waves because they travel faster in the Gulf of Naples. This is a direct effect of frequency dispersion. At Castellamare di Stabia, the $0.7 \mathrm{~m}$-high leading wave is followed by higher waves progressively reaching a maximum height of $1.5 \mathrm{~m}$ (Fig. 6).

\subsection{Probabilistic conditional hazard curves and maps}

We produced tsunami hazard curves that are conditional to subaqueous eruptions, since only eruptions with vent at sea are considered. Following Selva et al. (2018), the probability to have a vent at sea (depth $D>10 \mathrm{~m}$ ) given an eruption is approximately 0.11 (mean of the epistemic uncertainty). Given one eruption, the probability of being an explosive one is about 0.89 (mean of the epistemic uncertainty). Therefore, the probability to have a tsunamigenerating eruption conditional upon the occurrence of an eruption of any size in any vent at Campi Flegrei is approximately equal to $0.11 \times 0.89=0.10$ (again, mean of the epistemic uncertainty).

The main results of the PTHA are presented as conditional hazard curves for each of the 421 target points along the coast, conditional upon the occurrence of an eruption at sea, and their respective epistemic uncertainty. In Figure 7, we reported some example of conditional hazard curves and hazard maps (mean of the epistemic uncertainty) corresponding to an exceedance probability value of 0.05 , either relative to one specific eruption size or integrating all potential sizes. The value of 0.05 is chosen as a reference value as it is the same adopted for the real planning in this area (e.g. update of the National Emergency Plan for Campi Flegrei, 2016). More specifically, in the top three panels we reported the hazard maps conditional upon an explosive eruption at sea of size small (with representative radius $R=200 \mathrm{~m}$ ), medium $(R=650 \mathrm{~m})$, and large $(R=900 \mathrm{~m})$, respectively. In the bottom panel, we combined all potential eruption sizes (including the non-tsunami-generating effusive size, in analogy with Selva et al., 2008; 2018 and Sandri et al., 2016), reporting the conditional hazard map given an eruption at sea for any size.

The results for the single eruptive classes show that the tsunami intensities may be significant in case of explosive eruption at sea, with intensities corresponding to 0.05 exceedance probability (mean of the epistemic uncertainty) always significant ( $>1 \mathrm{~m}$ ) inside the Pozzuoli bay, reaching tens of meters for medium and large explosive eruption classes (Fig. 7). In the case of medium and, even more, large explosive eruptions, significant intensities were found 
also in many areas of the larger Bay of Naples, with focalization point along the Sorrento 310 peninsula.

311 As observed for other hazards (e.g., tephra fallout in Sandri et al. 2016 and Selva et al. 2018),

312 the hazard maps integrating all sizes provide results similar to the one conditioned to medium 313 explosive eruption size, with slightly smaller intensity. Noteworthy, also integrating all 314 potential sizes, eruptions at sea determine a significant tsunami hazard in many areas of the 315 Bay of Naples, still with the largest potential intensities within the Pozzuoli Bay.

\section{Discussion}

Tsunami hazard related to subaqueous volcanic explosions in the study area, and particularly in the Pozzuoli Bay, is far from negligible, even if the probability for eruptions in the submarine part of the caldera is rather low. Considered largest scenarios of explosions $(R=900$ $\mathrm{m})$ generate waves higher than $10 \mathrm{~m}$ in the Pozzuoli Bay, but lower than $1.5 \mathrm{~m}$ in the Gulf of Naples. Wave refraction creates local amplification (e.g. eastern coast of Capri) that is well reproduced by the numerical models. The smallest explosions considered here $(R=200 \mathrm{~m}) \mathrm{do}$ not represent a high hazard in terms of tsunami generation (waves $<1 \mathrm{~m} \mathrm{high}$ ). However, the impact of such small tsunami waves should not be neglected on such densely populated coasts. Another difficulty in terms of potential hazard mitigation actions comes from the proximity of the tsunami source. The propagation of the tsunami in the entire Gulf of Naples takes only 15 minutes. Pozzuoli is affected in less than 2 minutes.

In this work, tsunami wave behaviour at the coast (e.g. wave breaking, interaction with coastal structures) and inundation inland were not simulated, because it would require highresolution terrain models (typically $1 \mathrm{~m}$ grid resolution). In the near future, such simulations could be conducted at the local scale, i.e. on areas of specific interest (e.g. harbours), using those at the larger scale as input (Lorito et al., 2015; Volpe et al., 2019).

Another limitation comes from the model of explosion itself. We considered that the size of the crater reflects the most powerful explosion at shallow depth, regardless the total number of explosions (Goto et al., 2001; Taddeucci et al., 2010). In fact, the morphology of the crater might result from multiple vertically and horizontally-migrating explosions (e.g. Valentine et al., 2012; 2015). Thus, assuming that the size of the crater corresponds to the size of the explosion might lead to an overestimation of the explosion energy in some cases. 
340 We also assumed that the explosion occurs at the sea floor or at the rim of a pre-existing 341 eruptive vent. However, the evolution of the vent geometry during the eruption (crater 342 excavation, growth of the ejecta ring) and location of the explosion inside the vent might have 343 an influence on tsunami generation. These relationships have never been tested 344 experimentally or numerically.

345 Due to computational cost, we reduced exploration of aleatory variability such as vent 346 position and its size. This limitation was compensated by introducing a rather large 347 uncertainty into simulation results. However, given the illustrative character of this 348 application, we did not exploit any detailed analysis to better constrain the uncertainty 349 quantification. Temporal rates of eruptions are also difficult to constrain and, for this reason, 350 we did not extend our results to absolute unconditional probabilities, in line with previous 351 studies of this type (e.g. Sandri et al. 2016; Selva et al. 2018). However, we note that hazard 352 curves conditional upon eruption may represent a direct input for decision making. Indeed, 353 being possible short-term forecast of eruptions (e.g., Selva et al., 2012b), emergency plans are 354 usually based on such conditional hazard estimations (e.g. update of the National Emergency 355 Plan for Campi Flegrei, 2016). The probability of vents at sea is also poorly constrained.

356 Only few hazard analyses include the submerged part of Campi Flegrei as potential area for 357 vent opening (Tonini et al., 2015). The presence of several major faults oriented NW-SE in 358 the central part of the Pozzuoli Bay (see Orsi et al. 1994 and Selva et al. 2012a) tends to 359 concentrate the probability of vent opening in this part of the submerged caldera. Ring-faults 360 along the southern rim of the caldera also represent potential sites for future eruptions 361 (Steinmann et al., 2018), but this has not been considered in this paper.

362 In this study, we considered only tsunami source generated by submarine volcanic explosions 363 at Campi Flegrei. However, other sources such as pyroclastic density currents entering the sea 364 or earthquakes and landslides should be integrated into the probabilistic analysis to avoid bias 365 in the tsunami hazard assessment (Grezio et al., 2015). For Campi Flegrei, submarine 366 explosions seem to be the dominating tsunami-generating volcanic process, given the topo367 bathymetric configuration of the caldera and the prevalence in the past of dilute pyroclastic 368 density currents. However, other significant sources of volcanic tsunamis are present in the 369 Bay of Naples, including Ischia (Paparo and Tinti 2017 and reference therein) and Vesuvius 370 (Tinti et al. 2004). The Euro-Mediterranean Tsunami Catalogue (Maramai et al., 2014) 371 describes the sea withdrawals, sea retreats, and sea oscillations associated to volcanic 
activities and reports tsunamis with intensity 2 (meaning waves lower than $1 \mathrm{~m}$ ), mainly associated to pyroclastic density currents generated during explosive eruptions at Mt. Vesuvius.

\section{Conclusion}

The conditional probabilistic hazard assessment for tsunamis generated by subaqueous volcanic explosions is presented for the Campi Flegrei caldera. The probability for eruptions in the submarine part of the caldera is rather low, but scenarios of tsunamis generated by subaqueous volcanic explosions and their potentially high impact in the Pozzuoli Bay and Gulf of Naples deserve to be considered due to high population density of these coastal areas. We demonstrated that tsunamis from volcanic explosions in the Campi Flegrei caldera represent a significant source of hazard in the Pozzuoli Bay and Gulf of Naples. This is often overlooked, but should be integrated into the evaluation of natural hazards of the area. Highest hazard is found on the coasts of the Pozzuoli Bay, where incoming tsunami waves exceeding locally $10 \mathrm{~m}$ can be expected in case of future large explosions. Around Naples, where coasts are densely populated, the hazard is lower, but tsunamis exceeding $1 \mathrm{~m}$ are assessed. In this study, we considered tsunamis generated by volcanic explosions only, but other tsunamis sources such as earthquakes or landslides should be included in the future to fully evaluate the hazard in the region. Future developments could be the evaluation of a complete PTHA due to volcanic processes in the Campania region considering underwater caldera explosions, landslides, and pyroclastic density currents both from Vesuvius and Campi Flegrei eruptions.

\section{Acknowledgements}

This research was financed by the French Government Laboratory of Excellence initiative ${ }^{\circ}$ ANR-10-LABX-0006, the Region Auvergne, the European Regional Development Fund, and ASTARTE collaborative project FP7-ENV2013 6.4-3. M.Ulvrova has received funding from the European Union's Horizon 2020 research and innovation programme under the Marie Sktodowska-Curie grant agreement No.753755. We wish to thank G. Vilardo (Laboratory of Geomatics and Cartography, INGV-OV) for providing the topo-bathymetric data of the 


\section{References}

405

406

407

408

409

410

411

412

413

414

415

416

417

418

419

420

421

422

423

424

425

426

427

428

429

430

Aiello, G., Marsella, E., Di Fiore, V., 2012. New seismo-stratigraphic and marine magnetic data of the Gulf of Pozzuoli (Naples Bay, Tyrrhenian Sea, Italy): inferences for the tectonic and magmatic events of the Phlegrean Fields volcanic complex (Campania). Marine Geophysical Research 33, 97-125.

Albert P.G., Giaccio B., Isaia R., Costa A., Niespolo E.M., Nomade S., Pereira A., Renne P.R., Hinchliffe A., Mark D.F., Brown R.J., Smith V.C. (2019) Evidence for a large magnitude eruption from Campi Flegrei caldera (Italy) at 29 ka, Geology, doi: 10.1130/G45805.1

Auker, M.R., Stephen, R., Sparks, J., Siebert, L., Crosweller, H.S., Ewert, J., 2013. A statistical analysis of the global historical volcanic fatalities record Journal of Applied VolcanologySociety and Volcanoes, 2:2

Belousov, A., Voight, B., Belousova, M., Muravyev, Y., 2000. Tsunamis generated by underwater volcanic explosions: unique data from 1996 eruption in Karymskoye Lake, Kamchatka, Russia. Pure and Applied Geophysics 157, 1135-1143.

Bevilacqua, A., Flandoli, F., Neri, A., Isaia, R., Vitale, S., 2016. Temporal models for the episodic volcanism of Campi Flegrei caldera (Italy) with uncertainty quantification, Journal of Geophysical Research, Solid Earth 121, 7821-7845.

Bruno, P.P., 2004. Structure and evolution of the Bay of Pozzuoli (Italy) using marine seismic reflection data: implication for collapse of the Campi Flegrei caldera. Bulletin of Volcanology 66, 342-355.

Costa, A., Dell'Erba, F., Di Vito, M.A., Isaia, R., Macedonio, G., Orsi, G., Pfeiffer T., 2009. Tephra fallout hazard assessment at the Campi Flegrei caldera (Italy). Bulletin of Volcanology 71, 259-273.

Craig, B.G., 1974. Experimental observations of underwater detonations near the water surface. Los Alamos Scientific Laboratory of the University of California, report LA5548-MS, UC-34. 
D'Argenio, B., Aiello, G., de Alteriis, G., Milia, A., Sacchi, M., Tonielli, R., Angelino, A., Budillon, F., Chiocci, F., Conforti, A., De Lauro, M., Di Martino, G., d'Isanto, C., Esposito, E., Ferraro, L., Iannagi, S., Insinga, D., Iorio, M., Marsella, E., Molisso, F., Morra, V., Passaro, S., Pelosi, N., Porfido, S., Raspini, A., Ruggieri, S., Sarnacchiaro, G., Terranova, C., Vilardo, G., Violante, C., 2004. Digital elevation model of the Naples bay and adjacent areas (Eastern Tyrrhenian sea). In: Pasquaré, G., Venturini, C., Groppelli, G. (eds.) Mapping Geology in Italy. Ed. APAT (Roma), Dipartimento Difesa del Suolo-Servizio Geologico d'Italia (S.EL.CA. Firenze), 21-28.

Davies, G., Griffin, J., Løvholt, F., Glimsdal, S., Harbitz, C.B., Thio, H.K., Lorito, S., Basili, R., Selva, J., Geist, E., Baptista, M.A., 2017. A global probabilistic tsunami hazard assessment from earthquake sources. Geological Society, London, Special Publications, 456,579 .

Deino, A.L., Orsi, G., de Vita, S., Piochi, M., 2004. The age of the Neapolitan Yellow Tuff caldera-forming eruption (Campi Flegrei caldera-Italy) assessed by ${ }^{40} \mathrm{Ar} /{ }^{39} \mathrm{Ar}$ dating method. Journal of Volcanology and Geothermal Research 133, 157-170.

Di Vito, M.A., Isaia, R., Orsi, G., Southon, J., de Vita, S., D’Antonio, M., Pappalardo, L., Piocchi, M., 1999. Volcanism and deformation since 12,000 years at the Campi Flegrei caldera (Italy). Journal of Volcanology and Geothermal Research 91, 221-246.

Di Vito, A., Acocella, V., Aiello, G., Barra, D., Battaglia, M., Carandente, A., et al. (2016). Magma transfer at Campi Flegrei caldera (Italy) before the 1538 AD eruption. Scientific Reports 6, 32245.

Duffy, D.G., 1992. On the generation of oceanic surface waves by underwater volcanic explosions. Journal of Volcanology and Geothermal Research 50, 323-344.

Egorov, Y., 2007. Tsunami wave generation by the eruption of underwater volcano. Natural Hazards and Earth System Sciences 7, 65-69.

Geist, E.L., Lynett, P.J., 2014. Source processes for the probabilistic assessment of tsunami hazards. Special Issue on Undersea Natural Hazards, Oceanography, 27(2), 86-93.

Glimsdal, S., Løvholt, F., Harbitz, C.B., Romano, F., Lorito, S., Orefice, S., Brizuela, B., Selva, J., Hoechner, A., Volpe, M., Babeyko, A., Tonini, R., Wronna, M., Omira, R., 
2019. A new approximate method for quantifying tsunami maximum inundation height probability. Pure and Applied Geophysics, https://doi.org/10.1007/s00024-019-02091-w.

Goto, A., Taniguchi, H., Yoshida, M., Ohba, T., Oshima, H., 2001. Effects of explosion energy and depth to the formation of blast wave and crater: field explosion experiment for the understanding of volcanic explosion. Geophysical Research Letters 28, 4287-4290.

Grezio, A., Tonini, R., Sandri, L., Pierdominici, S., Selva, J., 2015. A Methodology for a Comprehensive Probabilistic Tsunami Hazard Assessment: Multiple Sources and ShortTerm Interactions. Journal of Marine Science and Engineering 3, 23-51.

Grezio, A., Babeyko, A., Baptista, M.A., Behrens, J. Costa, A., Davies, G., Geist, E.L., Glimsdal, S. Gonzàlez, F.I., Griffin, J., Harbitz, C.B., LeVeque, R.J., Lorito, S., Lövholt, F., Omira, R., Mueller, C., Paris, R., Parsons, T., Polet, J., Power, W., Selva, J., Sörensen, M.B., Thio, H.K., 2017. Probabilistic Tsunami Hazard Analysis: Multiple Sources and Global Applications. Reviews of Geophysics, 55.

Guidoboni, E., Ciuccarelli, C., 2011. The Campi Flegrei caldera: historical revision and new data on seismic crises, bradyseisms, the Monte Nuovo eruption and ensuing earthquakes (twelfth century 1582 AD). Bulletin of Volcanology 73, 655-677.

Kedrinskii, V.K., 2005. Hydrodynamics of Explosion. Springer, Berlin, Heidelberg.

Kirby, J.T., Wei, G., Chen, Q., Kennedy, A.B., Dalrymple, R.A., 1998. FUNWAVE 1.0, Fully nonlinear Boussinesq wave model. Documentation and users manual. Report CACR 9806, Center for Applied Coastal Research, Department of Civil and Environmental Engineering, University of Delaware.

Kokelaar, P., 1986. Magma-water interactions in subaqueous and emergent basaltic volcanism. Bulletin of Volcanology 48, 275-289.

Latter, J.N., 1981. Tsunamis of volcanic origin: summary of causes with particular references to Krakatoa, 1883. Bulletin of Volcanology 44, 467-490.

Le Méhauté, B.L., 1971. Theory of explosion-generated water waves. In: Chow, V.T. (Ed.) Advances in Hydroscience 7, Academic Press, New York, London, pp. 1-79.

Le Méhauté, B.L., Wang, S., 1996. Water waves generated by underwater explosion. Adv. Ser. Ocean Eng., World Sci., Volume10, New Jersey. 
Lorito, S., Selva, J., Basili, R., Romano, F., Tiberti, M.M., Piatanesi, A., 2015. Probabilistic hazard for seismically induced tsunamis: accuracy and feasibility of inundation maps. Geophysical Journal International, 200, 1, 574-588.

Maramai, A., Brizuela, B., Graziani, L., 2014. The Euro-Mediterranean Tsunami Catalogue. Annals of Geophysics, 57, 4, S0435.

Marti, A., Folch, A., Costa, A., Engwell, A., 2016. Reconstructing the plinian and coignimbrite sources of large volcanic eruptions: a novel approach for the Campanian Ignimbrite. Scientific Reports 6, 21220, 1-11.

Marzocchi ,W., Sandri, L, Selva, J., 2010. BET_VH: a probabilistic tool for long-time volcanic hazard assessment. Bulletin of Volcanology 72, 705-716.

Mirchina, N.R., Pelinovsky, E.N., 1988. Estimation of underwater eruption energy based on tsunami wave data. Natural Hazards 1, 277-283.

Morrissey, M., Gisler, G., Weaver, R., Gittings, M., 2010. Numerical model of crater lake eruptions. Bulletin of Volcanology 72, 1169-1178.

Newhall, C.G., Hoblitt, R.P., 2002. Constructing event trees for volcanic crises. Bulletin of Volcanology 64, 3-20.

Orsi, G., de Vita, S., Di Vito, M.A., 1996. The restless, resurgent Campi Flegrei nested caldera (Italy): constraints on its evolution and configurations. Journal of Volcanology and Geothermal Research 74, 179-214.

Orsi, G., Di Vito, M.A., Isaia, R., 2004. Volcanic hazard assessment at the restless Campi Flegrei caldera. Bulletin of Volcanology 66, 514-530.

Orsi, G., Di Vito, M.A., Selva, J., Marzocchi, W., 2009. Long-term forecast of eruption style and size at Campi Flegrei caldera (Italy). Earth and Planetary Science Letters 287, 265276.

Paparo, M.A., Tinti, S., 2017. Analysis of Seismic-Driven Instability of Mt. Nuovo in the Ischia Island, Italy. Bulletin of the Seismological Society of America 107, 750-759.

Paris, R., 2015. Source mechanisms of volcanic tsunamis. Philosophical Transactions of the Royal Society A 373, 20140380. 
Paris, R., Ulvrova, M., 2019. Tsunamis generated by subaqueous volcanic explosions in Taal Caldera Lake, Philippines. Bulletin of Volcanology 81, 14.

Sandri, L., Costa, A., Selva, J., Tonini, R., Macedonio, G., Folch, A., Sulpizio, R., 2016. Beyond eruptive scenarios: Assessing tephra fallout hazard from Neapolitan volcanoes. Scientific Reports, 6, 24271.

Sato, H., Taniguchi, H., 1997. Relationship between crater size and ejecta volume of recent magmatic and phreato-magmatic eruptions: implications for energy partitioning. Geophysical Research Letters 24, 205-208.

Selva, J., Costa, A., M.A., Marzocchi, W., Sandri, L., 2010. BET_VH: exploring the influence of natural uncertainties on long-term hazard from tephra fallout at Campi Flegrei (Italy). Bulletin of Volcanology 72, 717-733.

Selva, J., Orsi, G., Di Vito, M.A., Marzocchi, W., Sandri, L., 2012a. Probability hazard map for future vent opening at Campi Flegrei caldera, Italy. Bulletin of Volcanology 74, 497510.

Selva, J., Marzocchi, W., Papale, P., Sandri, L., 2012b. Operational eruption forecasting at high-risk volcanoes: the case of Campi Flegrei, Naples. Journal of Applied Volcanology 1:5.

Selva, J., Costa, A., Sandri, L., Marzocchi, W., 2014. Probabilistic short-term volcanic hazard in phases of unrest: a case study for tephra fallout. Journal of Geophysical Research 119(12), 8805-5526.

Selva, J., Tonini, R., Molinari, I., Tiberti, M. M., Romano, F., Grezio, A., Melini, D., Piatanesi, A., Basili, R., Lorito, S., 2016. Quantification of source uncertainties in Seismic Probabilistic Tsunami Hazard Analysis (SPTHA), Geophysical Journal International 205, 1780-1803.

Selva, J., Costa, A., De Natale, G., Di Vito, M.A., Isaia, R., Macedonio, G., 2018. Sensitivity test and ensemble hazard assessment for tephra fallout at Campi Flegrei, Italy. Journal of Volcanology and Geothermal Research 351, 1-28.

Shi, F., Kirby, J.T., Harris, J.C., Geiman, J.D., Grilli, S.T., 2012. A high-order adaptive timestepping TVD solver for Boussinesq modeling of breaking waves and coastal 
inundation. Ocean Modelling 43-44, 36-51.Steinman, L., Spiess, V., Sacchi, M., 2018. Post-collapse evolution of a coastal caldera system: insights from a 3D multichannel seismic survey from the Campi Flegrei caldera (Italy). Journal of Volcanology and Geothermal Research 349, 83-98.

550

Steinmann, L., Spiess, V., \& Sacchi, M. 2018. Post-collapse evolution of a coastal caldera system: Insights from a 3D multichannel seismic survey from the Campi Flegrei caldera (Italy). Journal of Volcanology and Geothermal Research, 349, 83-98.

Taddeucci, J., Sottili, G., Palladino, D.M., Ventura, G., Scarlato, P., 2010. A note on maar eruption energetics: current models and their applications. Bulletin of Volcanology 72, 75-83.

Tarquini, S., Isola, I., Favalli, M., Mazzarini, F., Bisson, M., Pareschi, M.T., Boschi, E., 2007. TINITALY/01: a new Triangular Irregular Network of Italy. Annals of Geophysics 50, 407-425.

Tehranirad, B., Shi, F., Kirby, J.T., Harris, J.C., Grilli, S., 2013. Tsunami benchmark results for fully nonlinear Boussinesq wave model FUNWAVE-TVD, Version 2.1. Research Report N ${ }^{\circ}$ CACR 13-10, Center for Applied Coastal Research, University of Delaware.

Tinti, S., Maramai, A., Graziani, L., 2004. The new catalogue of Italian tsunamis. Nat. Hazards 33, 439-465

Tonini, R., Sandri, L., Costa, A., Selva, J., 2015. Brief Communication: The effect of submerged vents on probabilistic hazard assessment for tephra fallout. Natural Hazards and Earth System Science 15, 409-415.

Torsvik, T., Paris, R., Didenkulova, I., Pelinovsky, E., Belousov, A., Belousova, M., 2010. Numerical simulation of explosive tsunami wave generation and propagation in Karymskoye Lake, Russia. Natural Hazards and Earth System Sciences 10 (11), 23592369.

Ulvrova, M., Paris, R., Kelfoun, K., Nomikou, P., 2014. Numerical simulations of tsunami generated by underwater volcanic explosions at Karymskoye Lake (Kamchatka, Russia) and Kolumbo volcano (Aegean Sea, Greece). Natural Hazards and Earth System Sciences 14, 401-412. 
575 Ulvrova, M., Paris, R., Nomikou, P., Kelfoun, K., Leibrandt, S., Tappin, D.R., McCoy, F.W., 2016. Source of the tsunami generated by the 1650 AD eruption of Kolumbo submarine volcano (Aegean Sea, Greece). Journal of Volcanology and Geothermal Research 321, 125-139.

Valentine, G.A., White, J.D.L., Ross, P.S., Amin, J., Taddeucci, J., Sonder, I., Johnson, P.J., 2012. Experimental craters formed by single and multiple buried explosions and implications for volcanic craters with emphasis on maars. Geophysical Research Letters 39, L20301.

Valentine, G.A., Graettinger, A.H., Macorps, É., Ross, P.S., White, J.D.L., Döhring, E., Sonder, I., 2015. Experiments with vertically and laterally migrating subsurface explosions with applications to the geology of phreatomagmatic and hydrothermal explosion craters and diatremes. Bulletin of Volcanology 77 (3), 1-17.

Volpe, M., Lorito, S., Selva, J., Tonini, R., Romano, F., and Brizuela, B., 2019. From regional to local SPTHA: efficient computation of probabilistic tsunami inundation maps addressing near-field sources. Nat. Hazards Earth Syst. Sci., 19, 455-469.

Wohletz, K.H., 1986. Explosive magma-water interactions: thermodynamics, explosion mechanisms, and field studies. Bulletin of Volcanology 48, 245-264. 


\section{Figure captions}

594 Fig. 1. Location map of the study area. The Pozzuoli Bay corresponds to the southern emerged part of the Campi Flegrei caldera. Bathymetry by D'Argenio et al. (2004).

Fig. 2. A) Physical parameters controlling the initial displacement of the water surface and subsequent tsunami in case of subaqueous volcanic explosion: $E$ : explosion energy; $d$ : explosion depth; $D$ : total water depth around the volcanic cone; $R$ : eruptive vent radius; $\eta_{0}$ : initial water surface displacement. B) Location of the 17 explosion sites tested for tsunami simulations in the Pozzuoli Bay. C) Craters of past eruptions at Campi Flegrei. The size of the craters (circles) is used to determine the three classes of radii of eruptive vents (modified from Costa et al. (2009). D) Dense Rock Equivalent versus Vent radius showing the relationship between the erupted magma volume and the size of the vents.

Fig. 3. Bayesian Event Tree for Volcanic Hazard (BET_VH) for the Campi Flegrei caldera (modified from Selva et al., 2010) adopted in this study. In light grey, we report the nodes that are not quantified, due to the choice of conditioning the probabilities upon the occurrence of subaqueous explosions.

Fig. 4. Maximum water elevation for explosions at site \#1. Three cases of eruptive vent radius are distinguished (200, 650, and $900 \mathrm{~m}$ ), corresponding to explosion energies of $2.9 \times 10^{14}, 9.8 \times 10^{15}$, and $2.6 \times 10^{16} \mathrm{~J}$, respectively (see Table 1 ). Blue colour corresponds to water displacements inferior to $0.1 \mathrm{~cm}$. Dark blue areas at the edges of the computational domain represent a sponge layer that is prescribed at the grid boundaries in order to dump incoming waves and hence prevent reflections to form at the end walls.

Fig. 5. Maximum wave amplitude recorded at the coast (Hmax) as a function of distance along the coastline (starting from the NW) for 3 different explosion sites (\#4, \#7, and \#17). Cities of Pozzuoli, Naples, Torre del Greco, and Castellamare di Stabia are located at distances of $20,40,50$, and $65 \mathrm{~km}$, respectively.

Fig. 6. Wave heights generated by underwater explosions at site \#1 and recorded at the coast at 7 virtual tide gauge stations. Three different values of vent radii $(200,650$, and 900 m) are represented, corresponding to different energies of explosion.

Fig. 7. For each individual size class (rows 1 to 3 ) and their combinations (row 4), we report the conditional mean hazard maps for a probability threshold $=0.05$ (maps on the left) 
623

624

625

626

627

628

629

630

and the conditional hazard curves (mean and $10^{\text {th }}-90^{\text {th }}$ percentiles confidence interval) in one point (black square) within the city of Naples (red lines on the right). All hazards are conditional upon submarine explosive eruptions (SEE) of size 1 (top panel), size 2 (second top panel), size 3 (third top panel), and any size (bottom panel). Note that, for sizes 2 and 3 (medium and large vent radia), the hazard curves have probability approaching 1 for relatively small tsunami intensity, meaning that the exceedance of such intensity in that position approaches certainty in case of submarine eruptions of these sizes. 


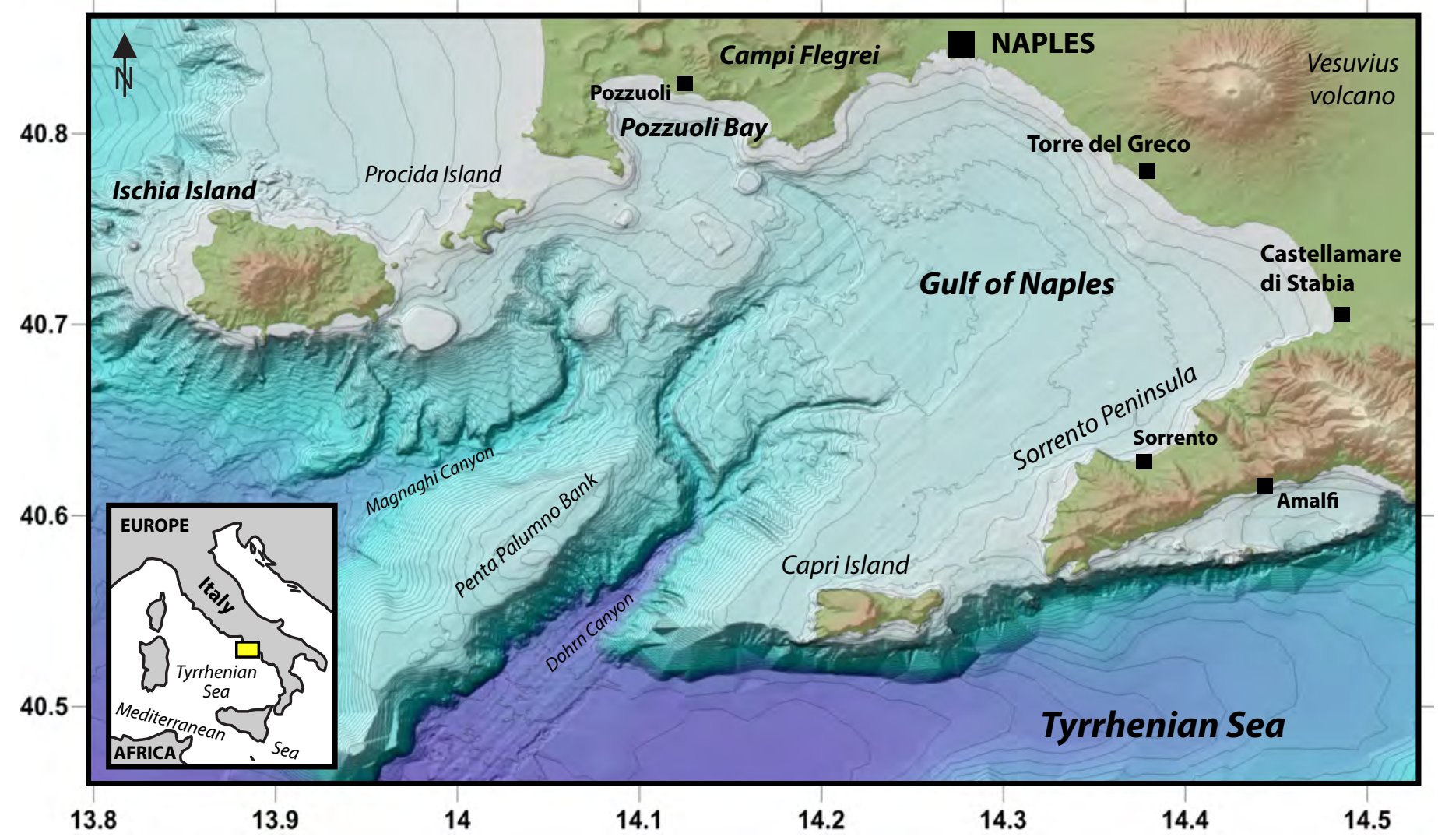



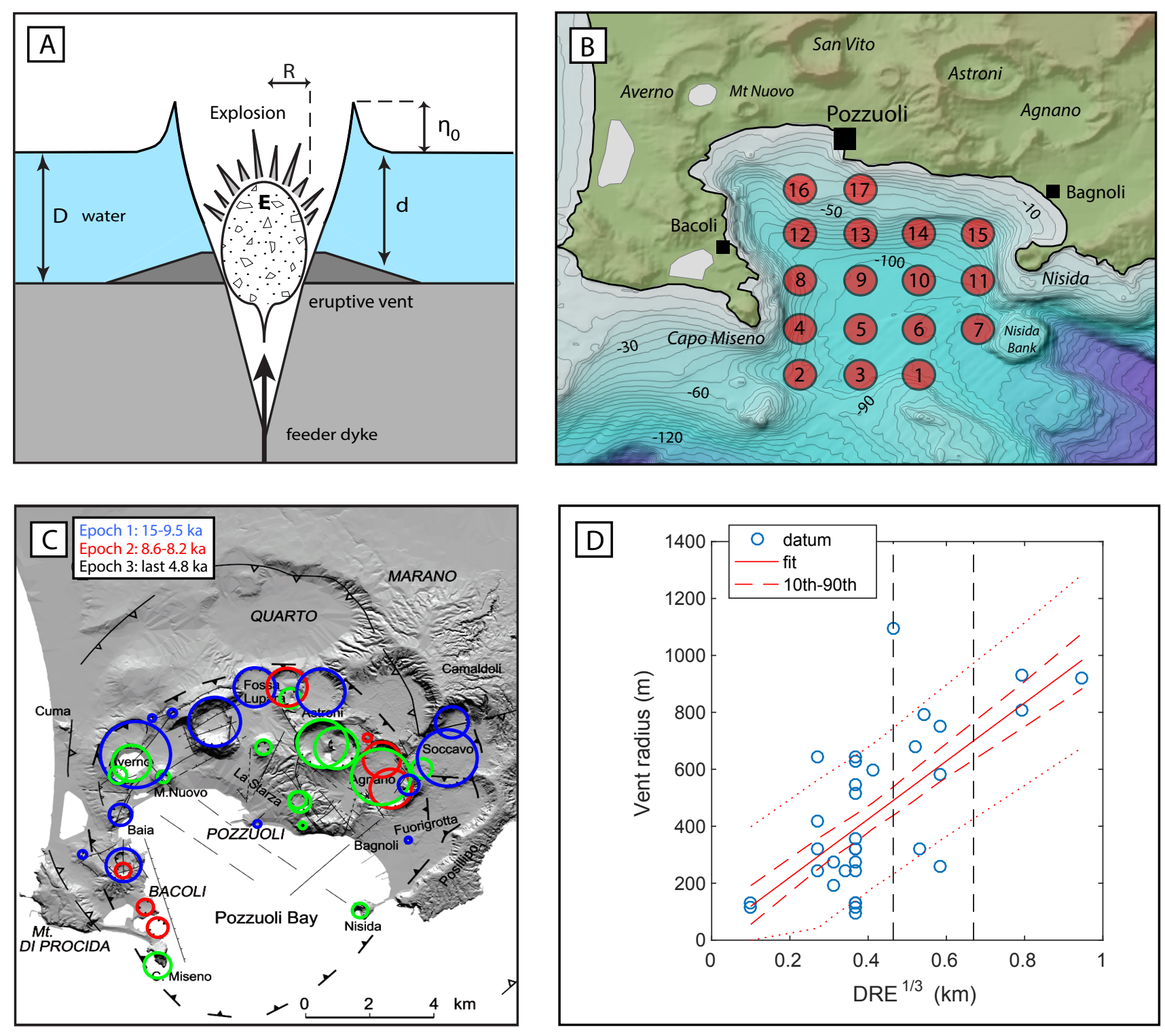


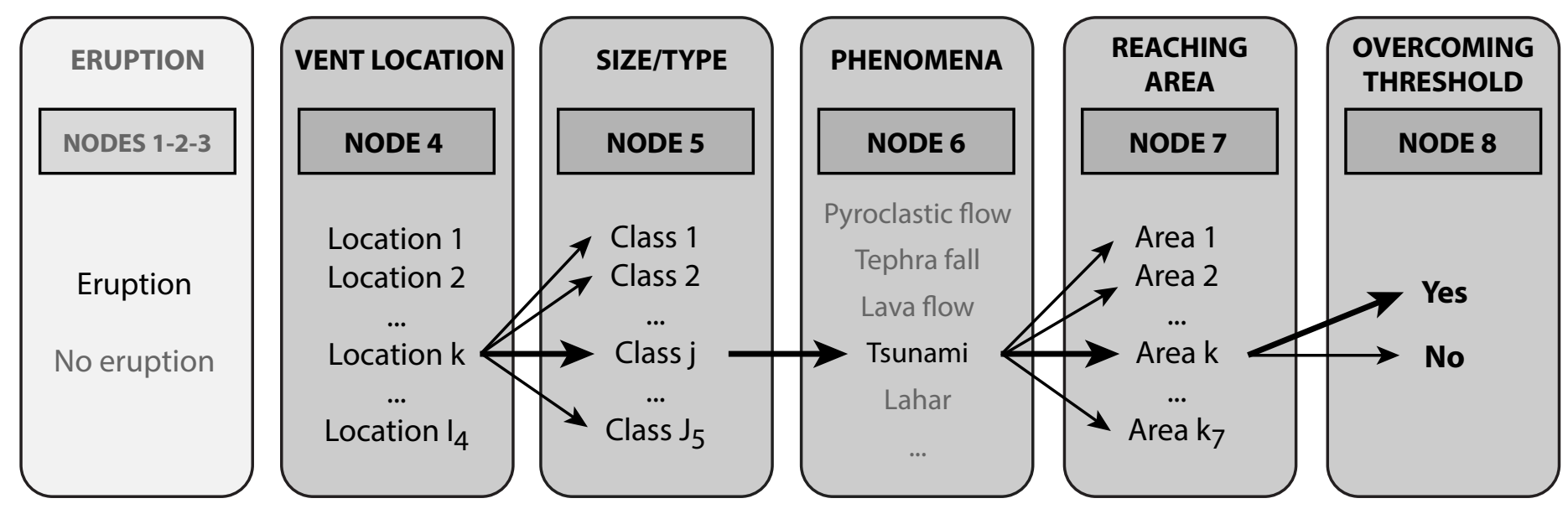


Explosion site \# 1
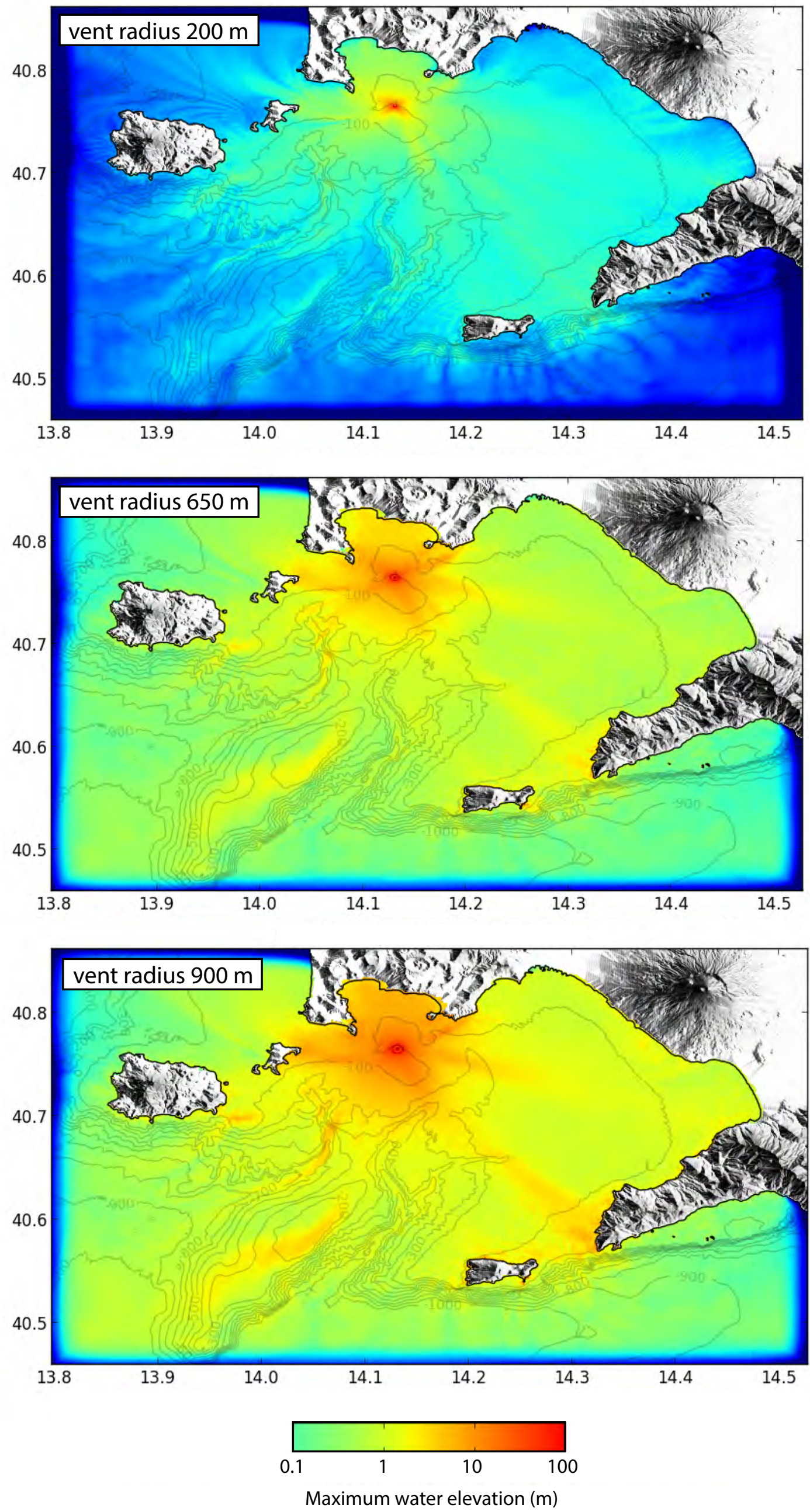


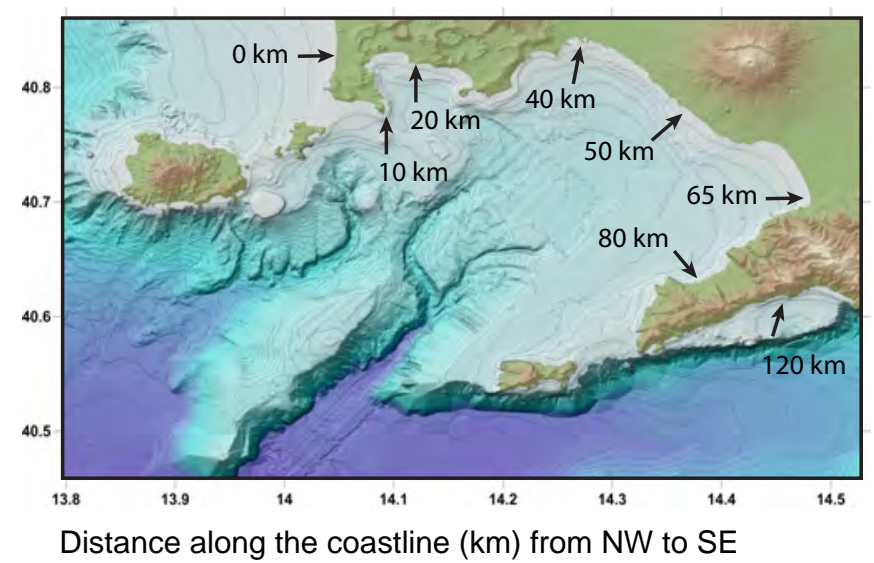

Vent radius (m)
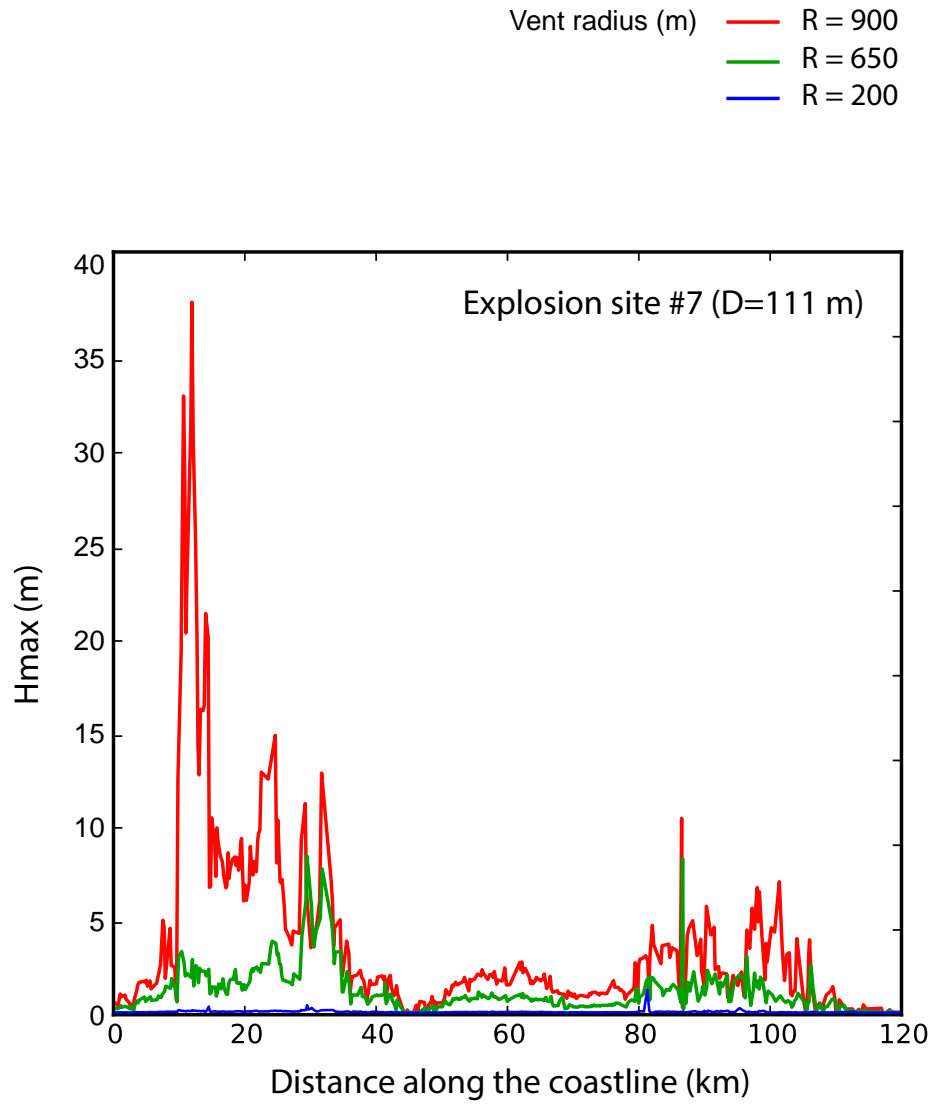
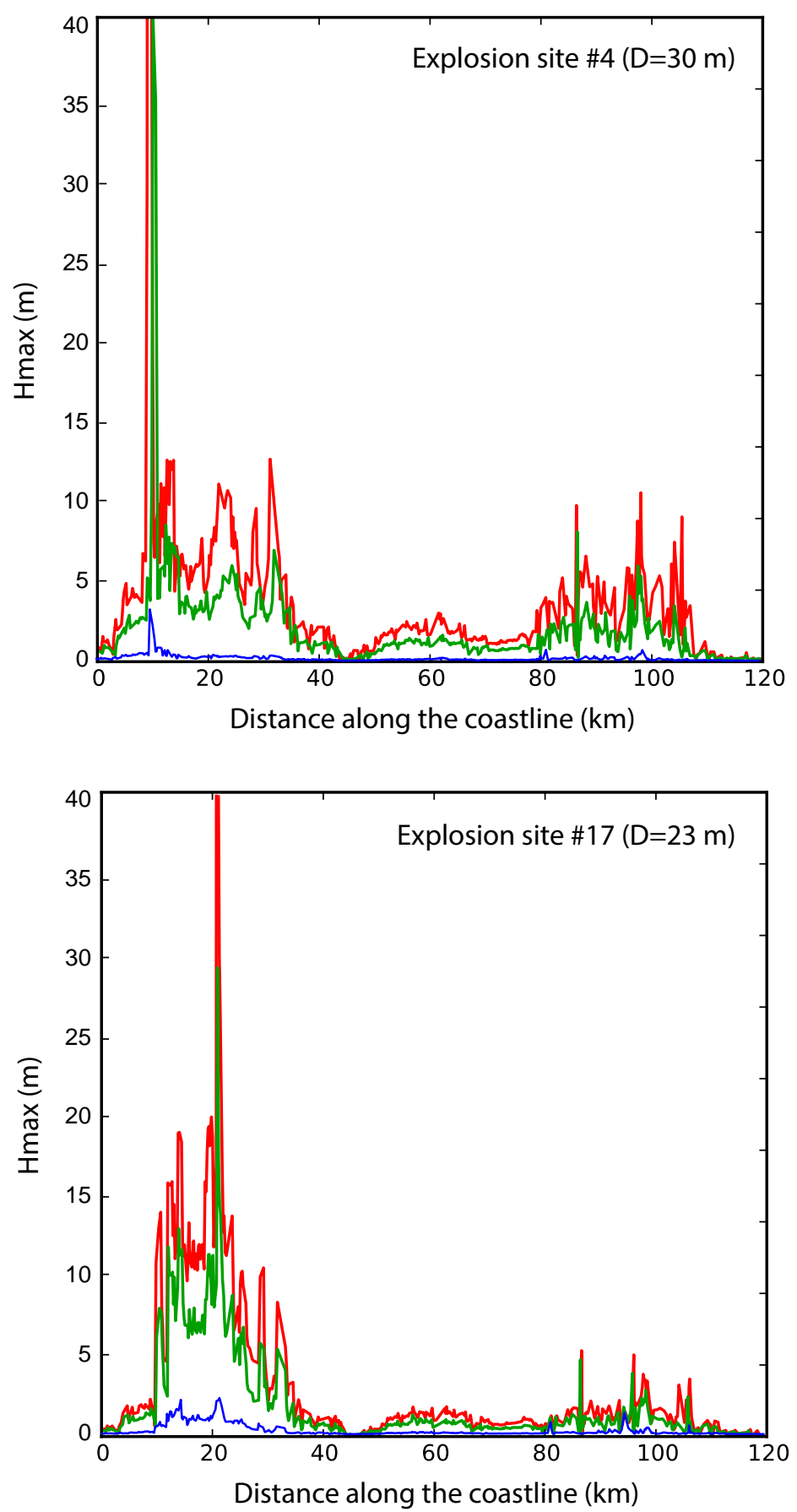

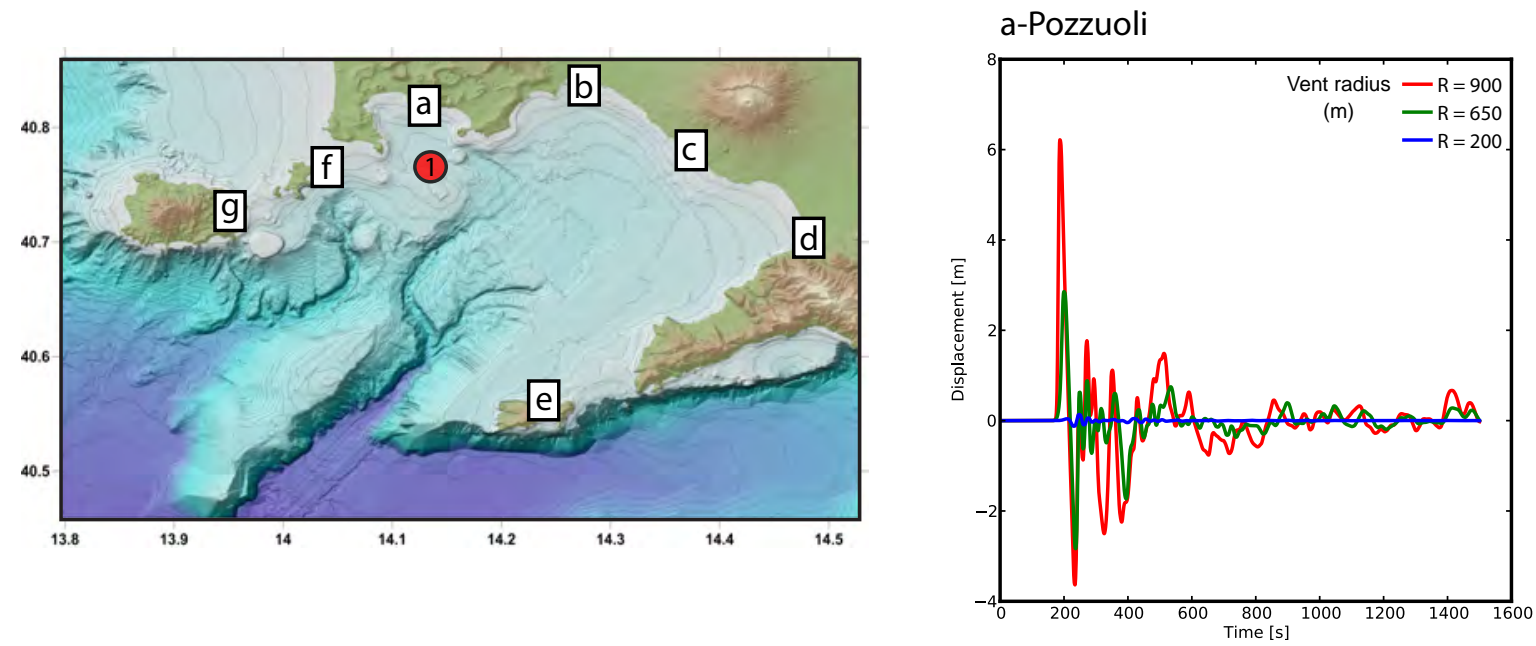

b-Naples
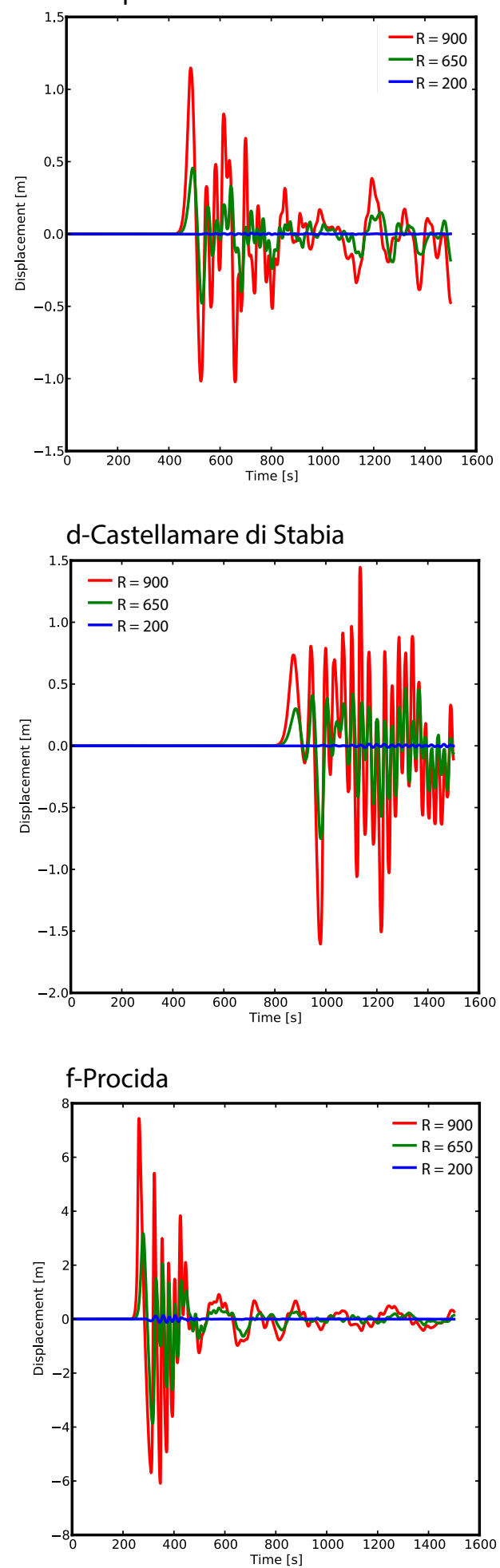

c-Torre del Greco
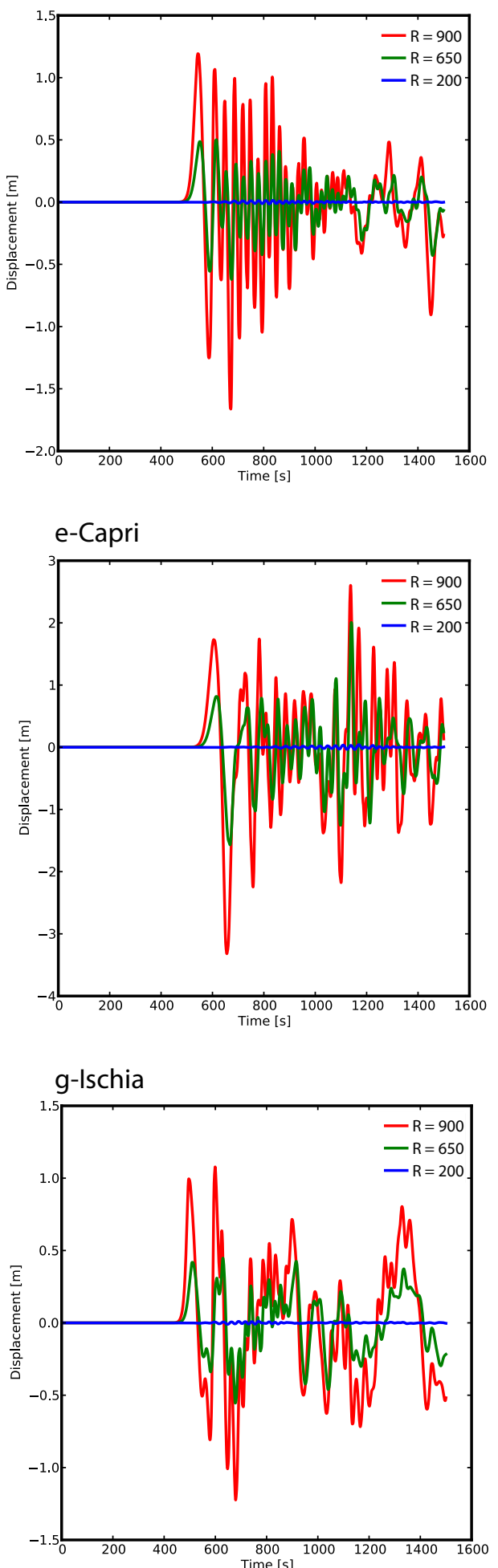

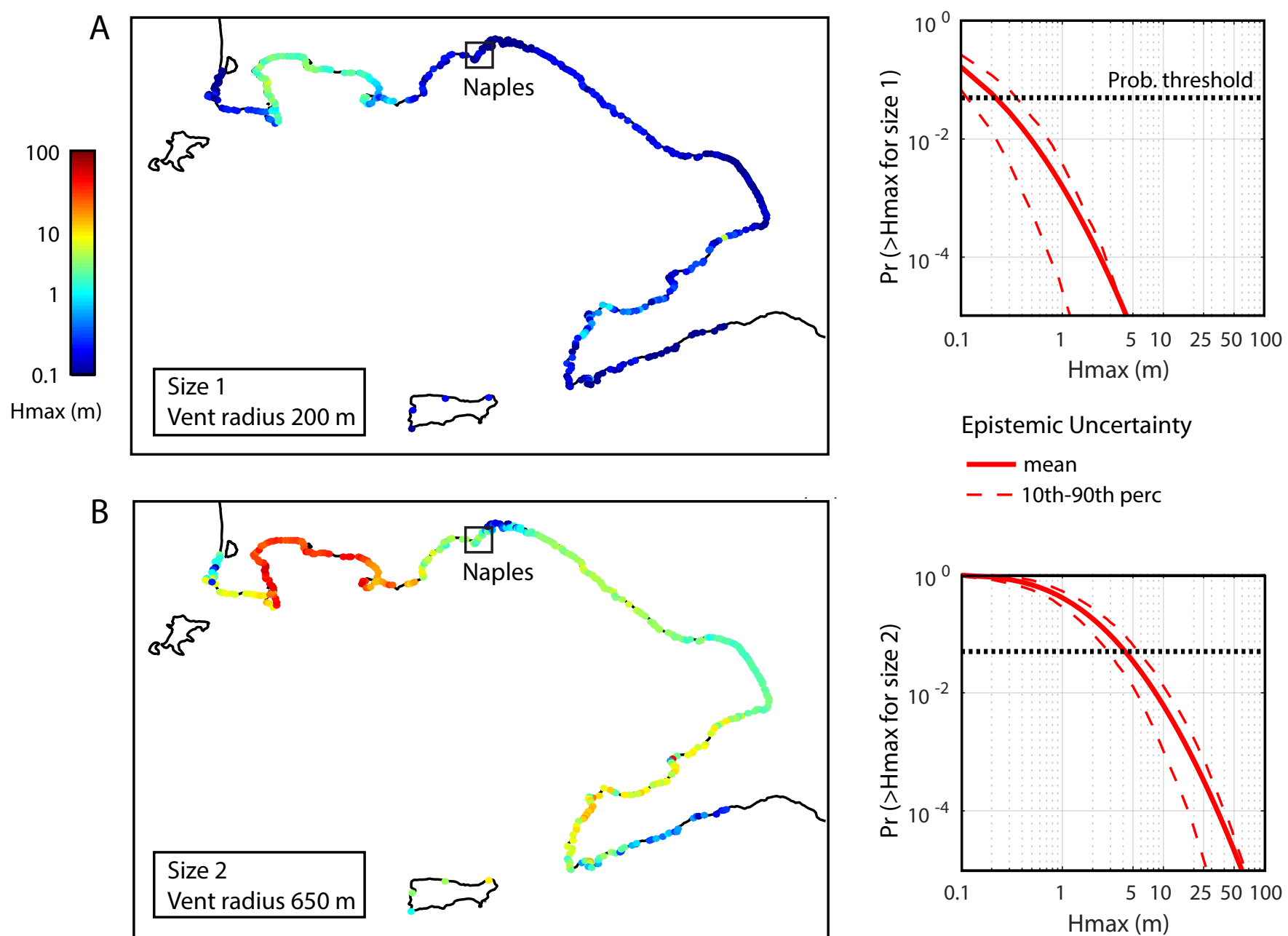

Epistemic Uncertainty

mean

- -10 th-90th perc

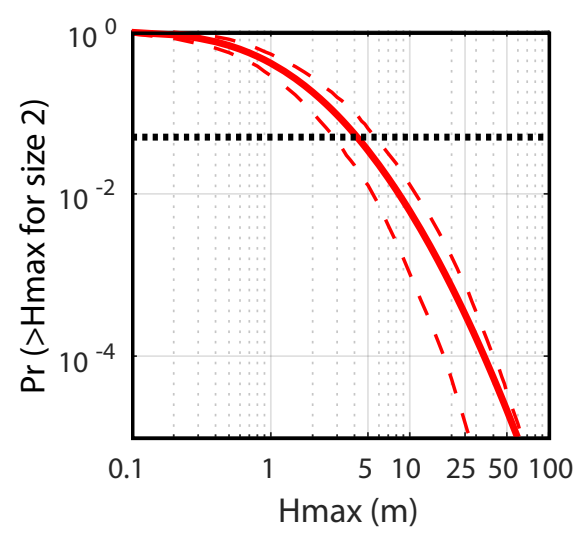

C
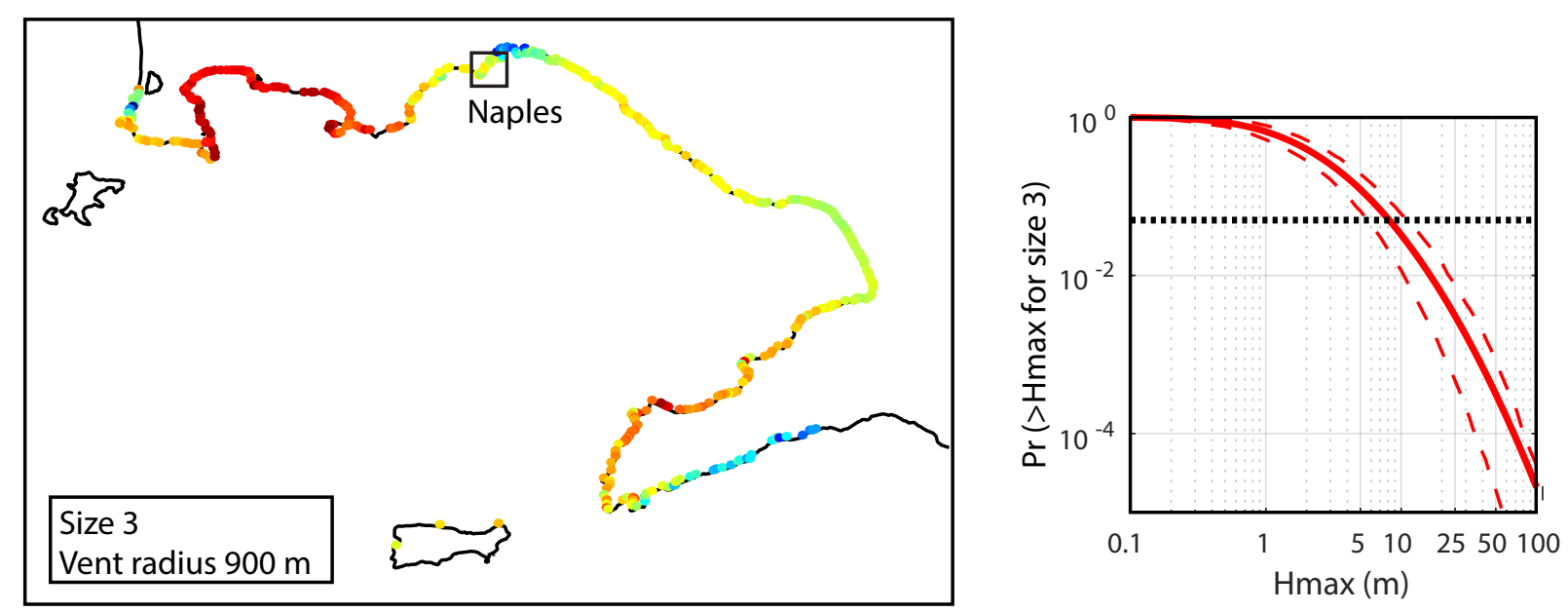

D
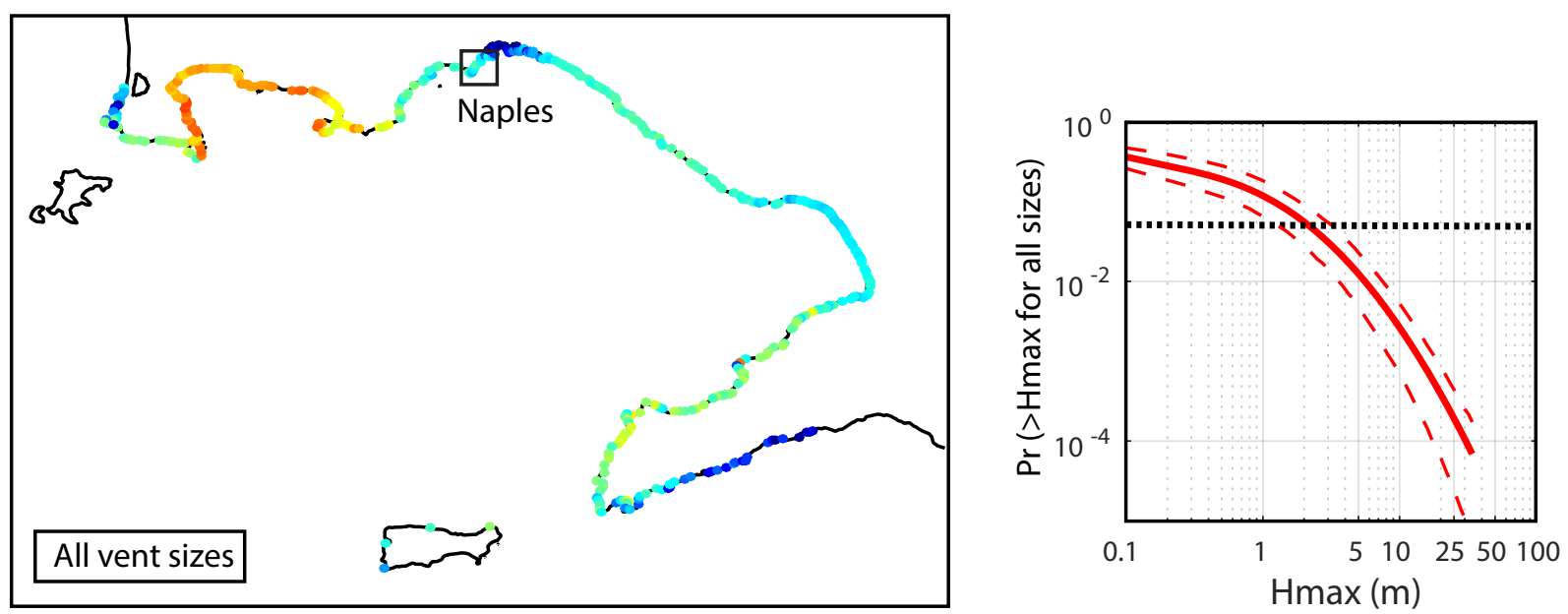
Table 1. Scenarios of subaqueous volcanic explosions. $d$ is explosion depth (similar to water depth in this case); $\mathrm{R}$ is radius of the eruptive vent; $\mathrm{E}$ is explosion energy; $\eta_{0}$ is initial displacement of the water surface.

\begin{tabular}{|c|c|c|c|c|c|c|}
\hline Explosion site & $\operatorname{long}\left({ }^{\circ}\right)$ & lat $\left(^{\circ}\right)$ & $\mathrm{d}(\mathrm{m})$ & $\mathrm{R}(\mathrm{m})$ & $E(J)$ & $\eta_{0}(\mathrm{~m})$ \\
\hline \multirow[t]{3}{*}{1} & 14.131004 & 40.76432 & 93 & 200 & $2.90 \mathrm{E}+14$ & 85 \\
\hline & & & & 650 & $9.80 \mathrm{E}+15$ & 200 \\
\hline & & & & 900 & $2.60 \mathrm{E}+16$ & 250 \\
\hline \multirow[t]{3}{*}{2} & 14.095464 & 40.764046 & 82 & 200 & $2.90 \mathrm{E}+14$ & 85 \\
\hline & & & & 650 & $9.80 \mathrm{E}+15$ & 200 \\
\hline & & & & 900 & $2.60 \mathrm{E}+16$ & 250 \\
\hline \multirow[t]{3}{*}{3} & 14.113234 & 40.764184 & 100 & 200 & $2.90 \mathrm{E}+14$ & 85 \\
\hline & & & & 650 & $9.80 \mathrm{E}+15$ & 200 \\
\hline & & & & 900 & $2.60 \mathrm{E}+16$ & 250 \\
\hline \multirow[t]{3}{*}{4} & 14.09528 & 40.777558 & 28 & 200 & $2.90 \mathrm{E}+14$ & 85 \\
\hline & & & & 650 & $9.80 \mathrm{E}+15$ & 200 \\
\hline & & & & 900 & $2.60 \mathrm{E}+16$ & 250 \\
\hline \multirow[t]{3}{*}{5} & 14.113054 & 40.777696 & 103 & 200 & $2.90 \mathrm{E}+14$ & 85 \\
\hline & & & & 650 & $9.80 \mathrm{E}+15$ & 200 \\
\hline & & & & 900 & $2.60 \mathrm{E}+16$ & 250 \\
\hline \multirow[t]{3}{*}{6} & 14.130828 & 40.777831 & 104 & 200 & $2.90 \mathrm{E}+14$ & 85 \\
\hline & & & & 650 & $9.80 \mathrm{E}+15$ & 200 \\
\hline & & & & 900 & $2.60 \mathrm{E}+16$ & 250 \\
\hline \multirow[t]{3}{*}{7} & 14.148602 & 40.777963 & 111 & 200 & $2.90 \mathrm{E}+14$ & 85 \\
\hline & & & & 650 & $9.80 \mathrm{E}+15$ & 200 \\
\hline & & & & 900 & $2.60 \mathrm{E}+16$ & 250 \\
\hline \multirow[t]{3}{*}{8} & 14.095097 & 40.791069 & 35 & 200 & $2.90 \mathrm{E}+14$ & 85 \\
\hline & & & & 650 & $9.80 \mathrm{E}+15$ & 200 \\
\hline & & & & 900 & $2.60 \mathrm{E}+16$ & 250 \\
\hline \multirow[t]{3}{*}{9} & 14.112875 & 40.791207 & 99 & 200 & $2.90 \mathrm{E}+14$ & 85 \\
\hline & & & & 650 & $9.80 \mathrm{E}+15$ & 200 \\
\hline & & & & 900 & $2.60 \mathrm{E}+16$ & 250 \\
\hline \multirow[t]{3}{*}{10} & 14.130652 & 40.791342 & 101 & 200 & $2.90 \mathrm{E}+14$ & 85 \\
\hline & & & & 650 & $9.80 \mathrm{E}+15$ & 200 \\
\hline & & & & 900 & $2.60 \mathrm{E}+16$ & 250 \\
\hline \multirow[t]{2}{*}{11} & 14.14843 & 40.791475 & 93 & 200 & $2.90 \mathrm{E}+14$ & 85 \\
\hline & & & & 650 & $9.80 \mathrm{E}+15$ & 200 \\
\hline
\end{tabular}




\begin{tabular}{|c|c|c|c|c|c|c|}
\hline & & & & 900 & $2.60 \mathrm{E}+16$ & 250 \\
\hline \multirow[t]{3}{*}{12} & 14.094914 & 40.80458 & 75 & 200 & $2.90 \mathrm{E}+14$ & 85 \\
\hline & & & & 650 & $9.80 \mathrm{E}+15$ & 200 \\
\hline & & & & 900 & $2.60 \mathrm{E}+16$ & 250 \\
\hline \multirow[t]{3}{*}{13} & 14.112695 & 40.804718 & 63 & 200 & $2.90 \mathrm{E}+14$ & 85 \\
\hline & & & & 650 & $9.80 \mathrm{E}+15$ & 200 \\
\hline & & & & 900 & $2.60 \mathrm{E}+16$ & 250 \\
\hline \multirow[t]{3}{*}{14} & 14.130476 & 40.804853 & 62 & 200 & $2.90 \mathrm{E}+14$ & 85 \\
\hline & & & & 650 & $9.80 \mathrm{E}+15$ & 200 \\
\hline & & & & 900 & $2.60 \mathrm{E}+16$ & 250 \\
\hline \multirow[t]{3}{*}{15} & 14.148257 & 40.804986 & 49 & 200 & $2.90 \mathrm{E}+14$ & 85 \\
\hline & & & & 650 & $9.80 \mathrm{E}+15$ & 200 \\
\hline & & & & 900 & $2.60 \mathrm{E}+16$ & 250 \\
\hline \multirow[t]{3}{*}{16} & 14.09473 & 40.818091 & 37 & 200 & $2.90 \mathrm{E}+14$ & 85 \\
\hline & & & & 650 & $9.80 \mathrm{E}+15$ & 200 \\
\hline & & & & 900 & $2.60 \mathrm{E}+16$ & 250 \\
\hline \multirow[t]{3}{*}{17} & 14.112515 & 40.818229 & 23 & 200 & $2.90 \mathrm{E}+14$ & 85 \\
\hline & & & & 650 & $9.80 \mathrm{E}+15$ & 200 \\
\hline & & & & 900 & $2.60 \mathrm{E}+16$ & 250 \\
\hline
\end{tabular}

